acids. ${ }^{73}$ Further investigation is necessary to provide an explanation.

We thank Dr J Bedrossian, Dr A Duboust, and Dr C Naret for allowing us to study patients under their care and Mrs J Siméon, Mrs J Rossi, and Mrs E Lancry for technical help.

This investigation was supported by research grant ATP 33 of the Institut National de la Santé et de la Recherche Médicale.

Request for reprints should be addressed to: $\mathrm{Dr} M$ Kazatchkine, Laboratoire d'Hémostase, et de Thrombose Expérimentale, Hôpital Saint-Louis, 2, Place du Dr A Fournier, 75475-Paris Cedex 10 France.

\section{References}

${ }^{1}$ Bouma, B N, et al, Nature New Biology, 1972, 236, 104.

2 Weiss, H J, et al, Fournal of Clinical Investigation, 1973, 52, 2708.

${ }^{3}$ Larsson, S O, Scandinavian Fournal of Haematology, 1971, 15, Suppl.

${ }^{4}$ Holmberg, L, and Nilsson, I M, Scandinavian fournal of Haematology, 1974, 12, 221.
${ }^{5}$ Hellem, A J, Odegaard, A E, and Skalhegg, A, in Abstracts of the Xth Congress of the International Society of Haematology, Stockholm, 1964.

${ }^{6}$ Salzman, E W, and Neri, L L, Thrombosis et Diathesis Haemorrhagica, 1966, 15, 94.

${ }^{7}$ Rabiner, S F, in Progress in Haemostasis and Thrombosis, ed T H Spaet, vol 1, p 233. New York, Grune and Stratton, 1973.

${ }^{8}$ Laurell, C B, Scandinavian Fournal of Clinical and Laboratory Investigation, 1972, 29, suppl No 124, p 21.

${ }^{9}$ Sultan, Y, Siméon, J, and Caen, J P, fournal of Clinical Pathology, 1975, 28, 309.

10 Marchesi, S L, Shulman, N R, and Gralnick, H R, fournal of Clinical Investigation, 1972, 51, 2151.

11 Castaldi, P A, Rozenberg, M C, and Stewart, J H, Lancet, 1966, 2, 66.

12 Evans, E P, Branch, R A, and Bloom, A L, fournal of Clinical Pathology, 1972, 25, 745.

13 Horowitz, H I, et al, American fournal of Medicine, 1970, 49, 336

14 Boneu, B, et al, Lancet, 1975, 1, 1430.

$15 \mathrm{Jaffe}, \mathrm{E} \mathrm{A}$, and Nachman, R L, fournal of Clinical Investigation, 1975, 56, 698.

${ }^{16}$ Hoyer, J R, Michael, A F, and Hoyer, L W, Fournal of Clinical Investigation, 1974, 53, 1375.

\title{
A new look at the neonatal electrocardiogram
}

\section{P SOUTHALl, D G VULliamy, M J DAVIES, R H ANDERSON, E A SHINEbOURNE, A M JOHNSON}

the start of the study there seemed to be at least three reasons why such a study might be valuable.

Firstly, it would enable the normal range of variation in the neonatal ECG to be assessed more accurately. This assessment would be based on statistical analysis and follow-up of many normal and abnormal records. Secondly, it would determine whether a routine neonatal ECG could be useful in the early detection of congenital heart disease. Finally, it would establish prospectively whether there is a relation between conduction abnormalities, especially pre-excitation, and the sudden infant death syndrome (cot deaths).

Although the study is continuing, the results in the first year bore out some of these expectations, and we report them here. sufficiently serious to need treatment. Two babies died suddenly, one of whom had abnormal conduction on the ECG and histologically demonstrated abnormalities of the conducting system. This continuing prospective study may indicate a link between conducting tissue abnormalities and the sudden infant death syndrome. Ten babies had congenital cardiac anomalies, four of which were first discovered because of an abnormal screening cardiogram. Electrocardiography, a simple and noninvasive procedure, may be a valuable addition to the routine neonatal examination.

\section{Introduction}

A project was designed to evaluate the use of a standard electrocardiogram (ECG) as a screening device in the newborn. At

\section{Weymouth}

D P SOUTHALL, MB, MRCP, family practitioner

Dorset County Hospital, Dorchester

D G VULLIAMY, MD, FRCP, consultant paediatrician

A M JOHNSON, MD, FRCP, consultant cardiologist

Department of Histopathology, St George's Hospital Medical School, London

M J DAVIES, MD, MRCPATH, reader and honorary consultant

\section{Cardiothoracic Institute, London}

R H ANDERSON, MD, MRCPATH, senior lecturer in paediatrics

E A SHINEBOURNE, MD, MRCP, senior lecturer and consultant paediatric cardiologist

\section{Patients and methods}

From April 1975 to April 1976818 babies who were kept in the local maternity unit for nine days after delivery were screened. The $35 \%$ of babies discharged at 48 hours were not included.

Standard ECGs were recorded using the portable Hewlett Packard machine Model 1504A. The usual paediatric plate electrodes were strapped to each limb and disposable Dracard electrodes were used for the chest leads. In addition to the limb leads, V1, V2, V4, and V6 were recorded; more recently VR4 was added.

ECGs were recorded between the 7 th and 10th day of life to exclude some of the haemodynamic changes that occur in the first week, during the transition from the fetal to the infant circulatory pattern.

To minimise the mothers' anxiety we told them about the test, explaining that the baby would feel no discomfort and that the procedure was completely safe and designed to supplement the routine clinical examination of the heart. The mother was told the result on the same day, only unequivocal abnormalities being mentioned. All infants with a definite ECG abnormality, together with those with any questionable anomaly or an "innocent murmur," were referred for follow-up, together with an equal number of randomly selected babies with normal ECGs to act as controls. The general practitioner was told of any significant abnormalities. The baby was usually seen for follow-up between 6 and 8 weeks of age, but he was seen earlier if an abnormality needed more careful evaluation. There was a high rate of attendance. Only eight babies failed to return, and all were alive and well at the time of writing.

Preterm babies and those of low birth weight were also included in the series because they have a higher incidence of cot death. ${ }^{12}$ The criteria for normality in the ECGs of these infants are slightly different from those for term babies. 


\section{Results}

\section{CONDUCTION ABNORMALITIES}

Twelve babies showed varying abnormalities of conduction (table I).

TABLE I-Conduction abnormalities shown by ECG.

\begin{tabular}{|c|c|c|c|}
\hline \multirow{2}{*}{$\begin{array}{l}\text { Case } \\
\text { No }\end{array}$} & \multicolumn{2}{|r|}{ Electrocardiogram } & \multirow{2}{*}{ Clinical features } \\
\hline & Age & Findings & \\
\hline 1 & $\begin{array}{l}6 \text { weeks } \\
8 \text { weeks }\end{array}$ & $\begin{array}{l}\text { Wolff-Parkinson-White syndrome } \\
\text { type A, accessory pathway close } \\
\text { to left side of interventricular } \\
\text { septum } \\
\text { Intermittent conduction through } \\
\text { accessory pathway } \\
\text { Normal conduction }\end{array}$ & Normal \\
\hline $2 *$ & $\begin{array}{l}4 \text { weeks } \\
8 \text { weeks }\end{array}$ & $\begin{array}{l}\text { Wolff-Parkinson-White } \\
\text { syndrome type A } \\
\text { Intermittent conduction } \\
\text { through accessory pathway } \\
\text { Normal conduction }\end{array}$ & $\begin{array}{l}\text { Delayed femoral pulses, } \\
\text { systolic murmur, } \\
\text { coarctation of the aorta }\end{array}$ \\
\hline 3 & $\begin{array}{l}8 \text { days } \\
9 \text { days } \\
9 \text { months }\end{array}$ & $\begin{array}{l}\text { Atrial tachycardia } 214 / \mathrm{min} \text {, with } \\
2: 1 \text { ventricular response } \\
\text { Sinus rhythm } \\
\text { Sinus rhythm }\end{array}$ & $\begin{array}{l}\text { Treated with digoxin, } \\
\text { structurally normal heart } \\
\text { On maintenance lanoxin } \\
0.05 \mathrm{mg} / \text { day }\end{array}$ \\
\hline 4 & $\begin{array}{l}4 \text { weeks } \\
6 \text { weeks }\end{array}$ & $\begin{array}{l}\text { Multiple APBs arising mid- } \\
\text { anterior right atrium with } \\
\text { episodes of atrial tachycardia at } \\
200 \text { beats/min originating in } \\
\text { same area } \\
\text { Continuous supraventricular } \\
\text { tachycardia } 187 / \text { min } \\
\text { Frequent ectopic beats still } \\
\text { present but only short } \\
\text { episodes of supraventricular } \\
\text { tachycardia }\end{array}$ & $\begin{array}{l}\text { Treated with digoxin } \\
\text { Maintenance lanoxin } \\
0.05 \mathrm{mg} / \text { day }\end{array}$ \\
\hline 5 & $\begin{array}{l}8 \text { days } \\
4 \text { weeks }\end{array}$ & $\begin{array}{l}\text { Multiple APBs } \\
\text { Less frequent extrasystoles }\end{array}$ & Normal \\
\hline 6 & 3 weeks & $\begin{array}{l}\text { Frequent APBs, prolonged P-R } \\
\text { interval } 0 \cdot 16 \mathrm{~s} \text {, intermittent } \\
\text { sinoatrial block with atrial or } \\
\text { junctional escape beats } \\
\text { Much more frequent APBs, } \\
\text { many conducted with } \\
\text { aberration }\end{array}$ & $\begin{array}{l}\text { Admitted to cardiac unit, } \\
\text { spontaneous onset of heart } \\
\text { failure while under } \\
\text { observation, treatment with } \\
\text { frusemide and digoxin, } \\
\text { cardiac catheterisation } \\
\text { normal, total disappearance } \\
\text { of APBs during } \\
\text { catheterisation with } \\
\text { shortening of } P-R \text { interval } \\
\text { to } 0 \cdot 12 \text { s. After catheter } \\
\text { study APBs returned and } \\
\text { remained present at } \\
8 \text { weeks of age, baby under } \\
\text { close observation }\end{array}$ \\
\hline & 6 months & Continuous sinus rhythm & \\
\hline 7 & $\begin{array}{l}8 \text { weeks } \\
16 \text { weeks }\end{array}$ & $\begin{array}{l}\text { Frequent VPBs arising in } \\
\text { posterior part of left ventricle, } \\
\text { time intervals compatible with } \\
\text { parasystole but because of } \\
\text { regular sinus rate could have } \\
\text { been coupled VPBs } \\
\text { VPBs not present }\end{array}$ & Normal \\
\hline 8 & $\begin{array}{l}8 \text { days } \\
1 \text { year }\end{array}$ & $\begin{array}{l}\text { Complete right bundle-branch } \\
\text { block, QRS } 0 \cdot 10 \mathrm{~s} \\
\text { No change }\end{array}$ & Normal \\
\hline 9* & $\begin{array}{l}8 \text { days } \\
5 \text { weeks }\end{array}$ & $\begin{array}{l}\text { Intermittent sinus tachycardia } \\
215 / \text { min } \\
\text { Sinus rhythm but complete } \\
\text { right bundle-branch block, } \\
\text { QRS } 0 \cdot 10 \mathrm{~s} \text {, mean QRS axis }+ \\
150^{\circ} \\
\text { Atrial tachycardia } 225 \text { beats } / \mathrm{min}\end{array}$ & $\begin{array}{l}\text { Systolic murmur, pulmonary } \\
\text { stenosis } \\
\text { Coincidental virus infection, } \\
\text { admitted to hospital }\end{array}$ \\
\hline 10 & $\begin{array}{l}8 \text { days } \\
6 \text { months }\end{array}$ & $\begin{array}{l}\text { Superior mean frontal QRS } \\
\text { axis }-45^{\circ} \text {, probable left } \\
\text { anterior hemiblock } \\
\text { No change }\end{array}$ & Normal \\
\hline $11^{*}$ & $\begin{array}{l}8 \text { days } \\
6 \text { weeks }\end{array}$ & $\begin{array}{l}\text { Superior mean frontal QRS } \\
\text { axis }-135^{\circ} \\
\text { Superior mean frontal QRS } \\
\text { axis }-90^{\circ}\end{array}$ & $\begin{array}{l}\text { Mitral systolic murmur, } \\
\text { fixed splitting second heart } \\
\text { sound } 0.03 \mathrm{~s} \text {, clinical } \\
\text { diagnosis of ostium primum } \\
\text { atrial septal defect }\end{array}$ \\
\hline 12 & $\begin{array}{l}8 \text { days } \\
6 \text { months }\end{array}$ & $\begin{array}{l}\text { Superior mean frontal QRS } \\
\text { axis }-90^{\circ} \text {, probable left } \\
\text { anterior hemiblock } \\
\text { No change }\end{array}$ & Normal \\
\hline
\end{tabular}

*See also table III. APBs $=$ Atrial premature beats. VPBs $=$ Ventricular premature beats.

\section{STRUCTURAL CONGENITAL HEART DISEASE}

Of the 818 neonates screened 10 had structural congenital heart disease. In four cases the condition was confirmed by catheter studies, and in the remaining six the diagnosis was made clinically. Six had definite clinical signs (table II), and the diagnosis could have been made by routine clinical examination alone. The other four cases (table III) were discovered at this early stage only because a screening ECG was recorded.

TABLE II-Congenital cardiac anomalies diagnosed clinically

\begin{tabular}{|c|c|c|c|}
\hline $\begin{array}{l}\text { Case } \\
\text { No }\end{array}$ & Clinical findings & Diagnosis & ECG findings \\
\hline 13 & Continuous murmur & $\begin{array}{l}\text { Patent ductus } \\
\text { arteriosus }\end{array}$ & $\begin{array}{l}\text { Long P-R interval } \\
0.16 \mathrm{~s}\end{array}$ \\
\hline 14 & Poor pulses & $\begin{array}{l}\text { Hypoplastic left } \\
\text { heart syndrome* }\end{array}$ & $\begin{array}{l}T \text { wave upright in } V 1 \text {, } \\
\text { no } R \text { wave } V 4-6\end{array}$ \\
\hline $\begin{array}{l}15 \\
16\end{array}$ & $\begin{array}{l}\text { Systolic murmur } \\
\text { Systolic murmur }\end{array}$ & $\begin{array}{l}\text { Ventricular septal defect } \\
\text { Ventricular septal } \\
\text { defect** }\end{array}$ & $\begin{array}{l}\text { Normal } \\
\mathrm{T} \text { wave upright V1 }\end{array}$ \\
\hline 17 & $\begin{array}{l}\text { Cyanosis and systolic } \\
\text { murmur }\end{array}$ & Tetralogy of Fallot* & \\
\hline 18 & $\begin{array}{l}\text { Prominent left } \\
\text { parasternal impulse }\end{array}$ & $\begin{array}{l}\text { Large ostium secundum } \\
\text { atrial septal defect* }\end{array}$ & $\begin{array}{l}\text { P-R interval } 0 \cdot 16 \mathrm{~s}, \\
\text { pure } R \text { wave V1 } 15 \mathrm{~mm}\end{array}$ \\
\hline
\end{tabular}

*Proved at cardiac catheterisation.

\section{OTHER ABNORMAL CARDIOGRAMS}

Another 37 recordings showed features that differed from normal. Three babies had resting tachycardias of between 195 and 210 beats/min. The P-wave configuration suggested that the rhythm was a sinus tachycardia, originating in the sinus node area. Many babies had a notched but not widened QRS complex, particularly in lead V1. In eight babies, however, there was widening of the QRS complex, to $0.06-0.08$ second, in association with a secondary $\mathrm{R}$ wave in lead V1. Babies with voltage values outside the $97 \%$ measurements were also selected for follow-up. Twenty-five babies had $\mathrm{R}$ waves in leads V1 greater than $23 \mathrm{~mm}$. One (case 19; table III) was found to have an ostium secundum atrial septal defect. Another incidental finding was an ECG showing a Q-T interval of 0.28 second, rate 150 beats/minute. This baby was found to have hypocalcaemia (serum calcium $1.90 \mathrm{mmol} / 1(7.6 \mathrm{mg} / 100 \mathrm{ml})$ ).

TABLE III-Congenital cardiac anomalies detected by abnormality of ECG

\begin{tabular}{|c|c|c|c|}
\hline $\begin{array}{l}\text { Case } \\
\text { No }\end{array}$ & $\begin{array}{l}\text { Clinical } \\
\text { findings } \\
\text { (age } 8 \text { days) }\end{array}$ & $\begin{array}{l}\text { Electrocardiogram } \\
\quad \text { (age } 8 \text { days) }\end{array}$ & $\begin{array}{l}\text { Diagnosis } \\
\text { (age } 2 \text { months) }\end{array}$ \\
\hline 11 & Normal & $\begin{array}{l}\text { Mean frontal QRS axis } \\
-135^{\circ}, \mathrm{RSR} \text { pattern V1 } \\
0.06 \mathrm{~s}\end{array}$ & $\begin{array}{l}\text { Ostium primum atrial septal } \\
\text { defect with mitral } \\
\text { incompetence }\end{array}$ \\
\hline 2 & Normal & $\begin{array}{l}\text { Wolff-Parkinson-White } \\
\text { syndrome type A }\end{array}$ & Coarctation of ihe atora \\
\hline 19 & Normal & $R$ wave in lead V1 $25 \mathrm{~mm}^{*}$ & $\begin{array}{l}\text { Ostium secundum atrial } \\
\text { septal defect }\end{array}$ \\
\hline 9 & Normal & $\begin{array}{l}\text { Complete right bundle- } \\
\text { branch block }\end{array}$ & Pulmonary stenosis \\
\hline
\end{tabular}

*97th percentile $23 \mathrm{~mm}$.

\section{INFANT DEATHS}

There were two sudden infant deaths in the present series. In both babies a definite cause of death was found at necropsy. In one there was an abnormality of the ECG.

Case 20-The diagnosis at necropsy was pneumococcal pneumonia. The ECG was normal. The histopathology of the heart and conducting tissues was normal (see fig, A and B).

Case 21-The diagnosis at necropsy was bacterial bronchopneumonia due to a Staphylococcus aureus infection. The ECG showed an R wave in lead V1 of $25 \mathrm{~mm}$, and the QRS complex showed considerable notching in the inferior leads. Histopathological examination of the conducting tissues showed the presence of a prominent right bundle branch but otherwise normal left bundle branches and bifurcation. The penetrating bundle was greatly elongated and narrowed (compare panels $\mathrm{B}$ and $\mathrm{D}$ in figure). The bundle penetrated unusually deep within the septum and made contact with the left side of the atrial septum. The compact node was small and the transitional zone was poorly developed (compare panels $\mathrm{A}$ and $\mathrm{C}$ in figure). There was no evidence of pathological change within the tissues of the junctional area, and accessory connections were not identified. 


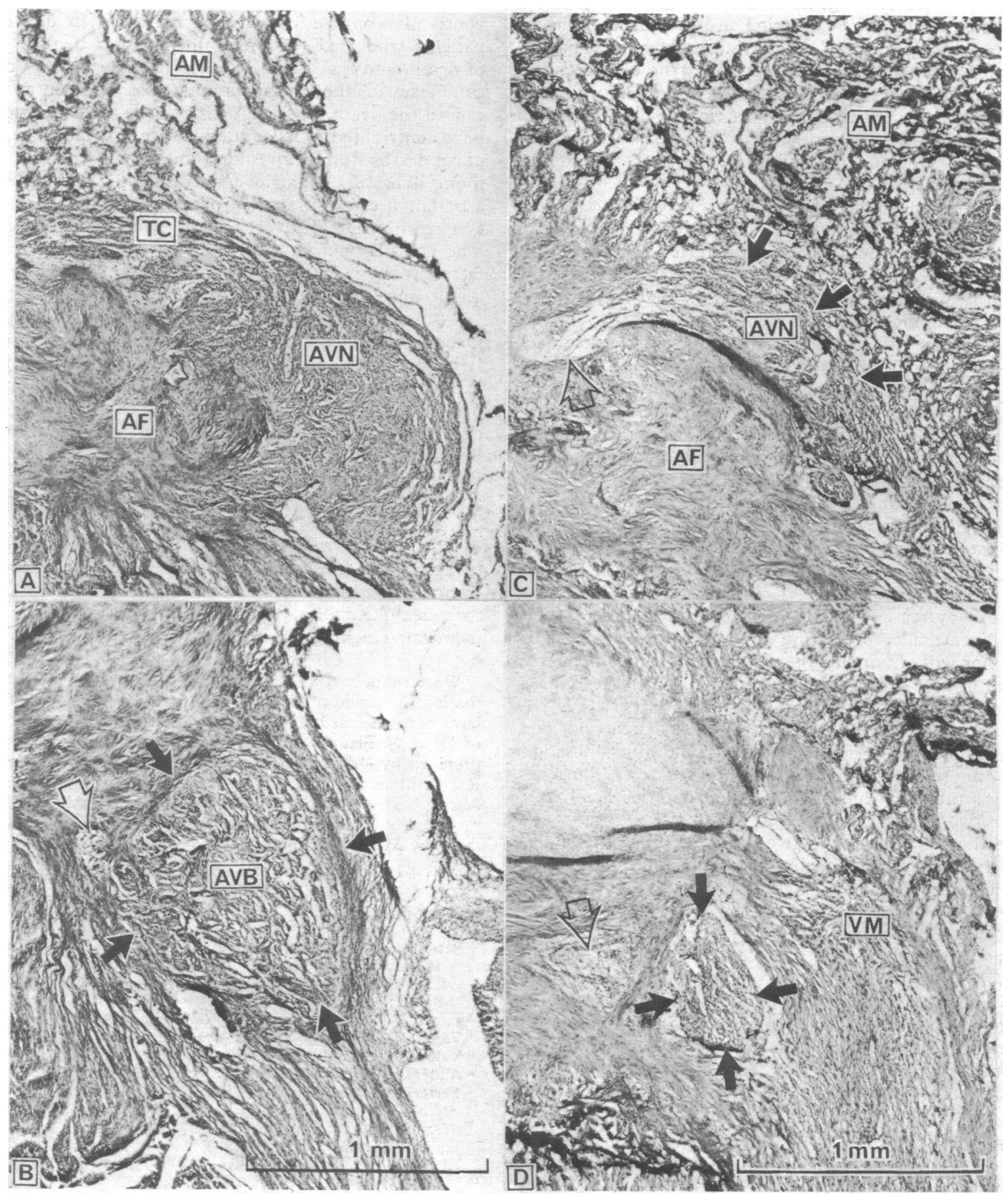

Panels A and B show sections of conducting tissue of first case of sudden death (case 20). Atrioventricular node (AVN) is normally formed with transitional cells (TC) seen between specialised nodal cells and atrial myocardium (AM). Node perforates through annulus fibrosus (AF) normally, and penetrating atrioventricular bundle (AVB) is illustrated in panel B. Dimensions of bundle are normal and small pocket of bundle tissue extends into annulus fibrosus (open arrow). This is also a normal finding. Panels $C$ and $D$ show conducting tissue from other infant who died suddenly, who showed ECG abnormalities (case 21). In this heart atrioventricular node was poorly formed and barely distinguishable from the atrial myocardium (panel $\mathrm{C}$ ). Arrows indicate junction between node and myocardium and open arrow indicates extension of node into annulus fibrosus. This hypoplastic node caused a considerably stenosed atrioventricular bundle (between arrows in panel D). Magnification is the same as that in panel B, and difference in size of the two bundles is readily apparent. Bundle is also separated from endocardial surface by ventricular myocardium (VM), and bundle tissue extends into annulus fibrosus (open arrows).

\section{Discussion}

The ECG in the neonatal period shows rapid changes associated with the transition from fetal to infant circulatory patterns and subsequently from neonatal to adult haemodynamics. Variability is also great and hence it is difficult to differentiate between the abnormal and the normal. Several workers have tried to overcome these problems, but few have followed up recordings into later infancy and childhood, and relatively small numbers have been used to obtain statistical results. We made no attempt to draw conclusions about the limits of normality. Only when more babies have been screened and followed up will these results be analysed. 
Our second aim was to investigate the value of a routine ECG as an early indicator of congenital heart disease. Many cases escape detection in the neonatal period and present later either through the chance finding of a heart murmur or occasionally after developing cardiac failure. Exceptionally the Eisenmenger syndrome may be present when the heart abnormality is first detected. Paediatric cardiac surgery is now well developed, and early diagnosis of congenital heart disease is important. Use of ECGs to supplement a full clinical examination might improve case detection.

Four cases of congenital cardiac anomalies were diagnosed earlier than would have been possible without the screening ECGs. Possibly these would have been detected later in childhood, but the knowledge that an infant has an abnormal heart, even though it does not require treatment at the time, may be important in managing an intercurrent illness.

Ten babies had conduction abnormalities. Two of these had the Wolff-Parkinson-White syndrome. The results of their follow-up will extend current knowledge about the development of this disorder. The presence of the arrhythmia at 8 days of age supports the view that the presence of an accessory pathway reflects a congenital malformation. It is of interest that there was no evidence of aberrant conduction on the subsequent ECGs performed at 6 and 8 months of age.

Five babies had a supraventricular arrhythmia, four of whom required treatment in hospital. One of these infants also had evidence of first degree atrioventricular block with a P-R interval of $0 \cdot 16$ second.

Only one baby (case 7) had a ventricular arrhythmia. The presence of ventricular premature beats is well recognised in adults, with or without organic heart disease, but this is poorly documented in normal infants. Congenital right bundle-branch block (case 8 ) is seen in adults and is benign.

Three babies had ECGs showing a superior or leftward axis deviation. One of these was diagnosed on clinical examination as having an ostium primum atrial septal defect. The axis deviation was probably due to isolated left anterior hemiblock in the other two infants.

The question of a relation between conducting system disorders and the sudden infant death syndrome has been discussed by several workers ${ }^{3-11}$ but is a contentious topic. Much of the disagreement relates to different interpretations of the significance of remnants of nodal tissue within the central fibrous body. All agree that this tissue is present in the hearts of both normal infants and those who die suddenly, but while some authorities believe that the tissue undergoes active "remoulding" 410 others consider that its presence within the central fibrous body is a consequence of the normal development of the atrioventricular junctional area. ${ }^{5611}$ Such disagreement should not, however, divert attention from the possibility that other conducting tissue abnormalities may play a part in causing sudden death.

James et $a l^{12}$ have recently shown that narrowing of the atrioventricular bundle can produce arrhythmias and sudden death in pug dogs. Although their study was not comparable in all respects with ours, it may be important that the atrioventricular bundle was greatly narrowed in one of our two patients who died suddenly, albeit with a demonstrable cause of death, and that the ECG showed abnormalities of the QRS complexes. Although pneumonia was present and probably caused the death, the conducting tissue abnormalities may well have contributed to its sudden nature. Furthermore, in a series of cot deaths studied by Anderson $e t a^{6}$ an accessory bundle was found bypassing the atrioventricular node in a single case, again a potential cause of sudden death. A link between conducting system disorders and cot deaths still deserves consideration. The link may not be direct, in that an additional precipitating factor such as a viral infection, milk allergy, or metabolic disturbance may be needed to provoke a fatal arrhythmia.

To the best of our knowledge no previous attempt has been made to show any possible relation by use of a prospective study. Because cot deaths occur in about 1 in every 400 live births ${ }^{12}{ }^{2}$ many thousands of ECGs will have to be carried out before a firm conclusion can be drawn about this problem. We hope that our study may offer a way out of the present impasse concerning histological observations and their conflicting interpretations. Possibly the early detection of certain types of conduction abnormality on the ECG may be a way of reducing the risk of cot death.

In summary, the recording of an ECG is simple and noninvasive, and the abnormality rate seems to be high when compared, for instance, with that found with the Guthrie test for phenylketonuria. We suggest that it might be a valuable neonatal screening procedure.

We are indebted to Professor $\mathrm{H} \mathrm{J} \mathrm{J} \mathrm{Wellens} \mathrm{for} \mathrm{his} \mathrm{interest} \mathrm{and} \mathrm{for}$ the interpretation of difficult ECGs. Our pathological studies would have been impossible without the willing co-operation and interest of Dr A N Blades. Considerable help in planning this project was provided by Drs A Leatham and D A Chamberlain. Drs J F Talbot, $\mathrm{R} J$ Brinton, and $\mathrm{M} J$ Orrell helped with the ECG recordings, and Mrs J J M Crosbie, Mrs E M Southall, and Miss T M Prangnell provided invaluable secretarial help. The photomicrographs were taken by $\mathrm{Mr} \mathrm{K}$ Moreman.

\section{References}

1 Bergman, A B, Beckwith, J B, and Ray, C G, Sudden Infant Death Syndrome. Seattle, University of Washington Press, 1970.

2 Camps, F E, and Carpenter, R G, Sudden and Unexpected Deaths in Infancy. Bristol, John Wright, 1972.

3 James, T N, American fournal of Cardiology, 1968, 22, 479.

4 Ferris, J A J, Medicine, Science and the Law, 1972, 12, 173.

5 Valdes-Dapena, M, et al, New England fournal of Medicine, 1973, 289, 1179.

6 Anderson, R H, et al, British Medical fournal, 1974, 2, 135.

7 Ferrer, M I, Cardiovascular Clinics, 1970, 2, 2.

${ }^{8}$ Ferris, J A J, British Medical fournal, 1973, 2, 23.

9 Bergman, A B, et al, Paediatrics, 1972, 49, 6, 860

10 James, T N, Circulation, 1976, 53, 1.

11 Lie, J T, et al, Circulation, 1976, 53, 1.

12 James, T N, et al, Circulation, 1975, 52, 1152. 